featured in this issue of PS. On Thursday evening Lucian W. Pye gave his Presidential address on Political Science and the Crisis of Authoritarianism.

\section{Highlights from Education Activities at the 1989 Annual Meeting}

The Association received a grant from the Ford Foundation to support a faculty development project to enhance research and teaching on the Bill of Rights and civil rights. The project provided support for four short seminars prior to the 1989 APSA Annual Meeting, whose participants were then able to attend Annual Meeting panels in the special sections devoted to the Bill of Rights and to the Civil Rights Act of 1964. The titles, directors and participants in each seminar were:

\section{Landmarks in the Judicial Interpretation of Civil Rights in America}

Director: Henry J. Abraham, University of Virginia

Participants:

Wayne F. Allen, University of Northern lowa

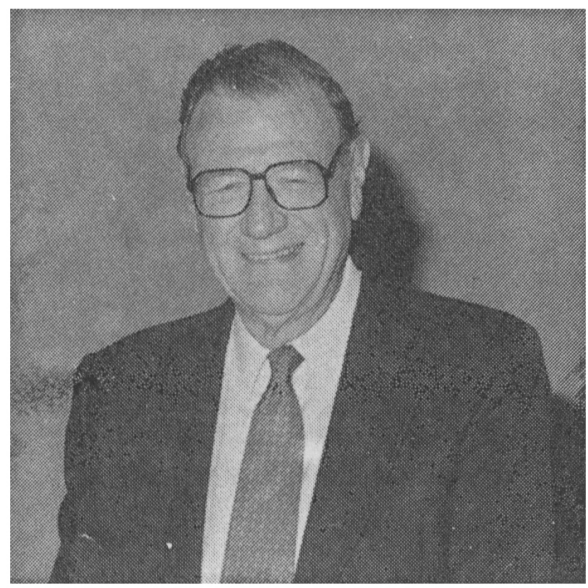

LUCIAN W. PYE

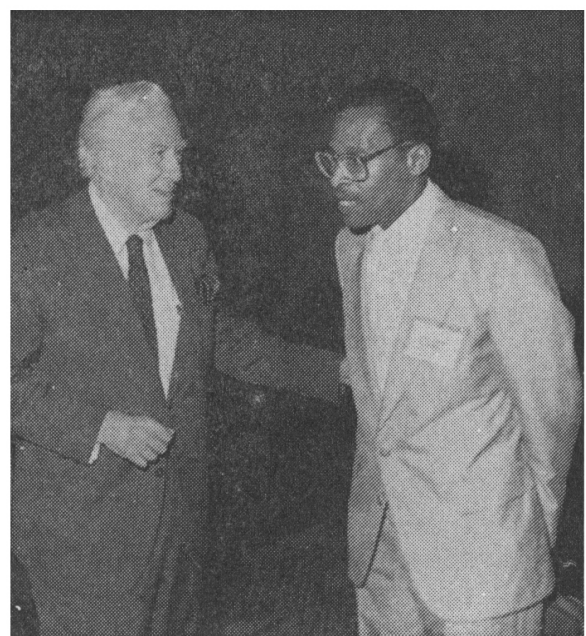

The Honorable Warren E. Burger, Chief Justice of the U.S. Supreme Court, retired, was honored at a reception hosted by the APSA section on Law, Courts and Judicial Process. Pictured here (l. to $r$.) Chief Justice Burger and William Daniels.

Alan I. Bigel, University of Wisconsin, LaCrosse Abraham L. Davis, Morehouse College Byron W. Daynes, DePauw University JeDon A. Emenhiser, Humboldt State University

Philip L. Fetzer, California Polytechnic State University

Ernest D. Giglio, Lycoming College

Lawrence Golden, Sangamon State University Timothy M. Hagle, University of lowa Janis Judson, Hood College

Francis Graham Lee, St. Joseph's University

Harold A. Lutchman, University of the Virgin Islands

John A. Maltese, University of Georgia

Janet M. Martin, Bowdoin College

Karen J. Maschke, University of Georgia

Amrut W. Nakhre, Atlantic Christian College

Huey L. Perry, Southern University

Stephen K. Shaw, Northwest Nazarene College

Robert C. Vipond, University of Toronto

Warren R. Wade, North Park College

\section{The Concept of Rights} as Limits on Government

Director: Jennifer Nedelsky, University of Toronto

Participants:

Gary J. Aichele, Juniata College 
Henry ]. Anna, Slippery Rock University Jane Bennett, Goucher College Eloise A. Buker, Gonzaga University Donald I. Budzinkai, King's College Uday Desai, Southern Illinois University Bette Novit Evans, Creighton University Michael T. Gibbons, University of South Florida Katy J. Harriger, Wake Forest University Paul Kens, Southwest Texas State University Ronald M. Labbe, University of Southwestern Louisiana

William Lasser, Clemson University Connie L. Lobur, SUNY-College at Purchase

Paul E. Parker, Northeast Missouri State University

Paul T. Persons, California State UniversityChico

Daniel W. Skubik, Nova University

Susan D. Sullivan, Georgetown University

Carol L. Tebben, University of WisconsinParkside

Elliot Tenofsky, Linfield College

Raymond B. Wrabley, University of Pittsburgh at Johnstown

\section{Civil Rights and Social Change: \\ The Contributions of Interest Groups, Social Movements and the Courts}

Director: Karen O'Connor, Emory University

Participonts:

Kenneth A. Betsalel, Southwest Missouri State University

John Brigham, University of Massachusetts, Amherst

Stephen L. Fisher, Emory and Henry College

Roy B. Flemming, Texas A\&M University

William Haltom, University of Puget Sound

Christine Harrington, New York University

Richard A. Harris, Rutgers University-Camden

Garry Jennings, St. Mary's College, Notre Dame, Ind.

Oliver 0 . Jones, Jr., Florida A\&M University

James $E$. Jordan, Ohio University, Zanesville

Daniel C. Kramer, College of Staten Island, City University of New York, St. George Campus

Eileen L. McDonagh, Henry A. Murray Research Center, Radcliffe College

Barbara A. Perry, Sweet Briar College

Steven A. Shull, University of New Orleans

Henry B. Sirgo, McNeese State University

Maren Stein, Russell Sage College

Douglas Turner, Alabama A\&M University

Laura R. Woliver, University of South Carolina, Columbia

\section{The Philosophical Roots of the Bill of Rights: The Federalists' and Anti-Federalists' Conception of Rights}

Director: Tom Pangle

Participants:

Danny M. Adkison, Oklahoma State University Susan Behuniak-Long, LeMoyne College Gerald De Maio, Baruch College, CUNY Ethan Fishman, University of South Alabama Stephen A. Graham, University of Indianapolis Ralph C. Hancock, Brigham Young University

Thomas K. Lindsay, University of Northern lowa

Gary Lee Malecha, Weber State College

Daniel J. McCarthy, College of New Rochelle Charles A. Miller, Lake Forest College

John Moeller, Luther College

Glenn A. Phelps, Northern Arizona University lames F. Pontuso, Hampderi-Sydney College John Riley, Jr., Coastal Carolina College

Richard Sobel, Princeton University

G. Alan Tarr, Rutgers University-Camden

John R. Vile, Middle Tennessee State University Leonard A. Williams Jr., Manchester College

Edward N. Wright, U.S. Air Force Academy

Preliminary analysis of evaluations submitted by the participants indicate that, for the most part, they found the program very useful and agreed that the Association should continue to offer comparable professional education programs. Many faculty volunteered comments on their experiences. One quotation is an illustrative sum of these comments:

The program seems to provide several unique and important opportunities. One is the chance to engage in intensive study of a topic with interested colleagues. A second is the chance to piggyback the seminars with the Annual Meeting to take advantage of the resources it provides. Finally, the chance to meet colleagues from around the country in a professional and social setting was very gratifying.

Educational reform is a matter of public concern and is being given high priority by foundations, corporations and learned societies. The considerable audience that came to the roundtable discussion, "Teaching Kids About Politics: Pre-College Education," is an indication that more political science faculty are being drawn to this issue. The session was organized by Thomas E. Cronin, Colorado College, and Howard Silver, Consortium of Social Sci- 
ence Associations. Other panelists were Mary Hepburn, University of Georgia, Lewis Lipsitz, University of North Carolina, and Sheilah Mann, APSA. Members of the audience participated, actively, in the session whose key points were:

- If we are concerned about political science education, we need to "reach kids" in elementary and middle school. If they are not engaged in political life and the study of politics before high school, students are likely to be apathetic or cynical.

- If political scientists are interested in influencing the curricula, then they need to work with their local schools, school districts and state agencies. Curricula decisions are made at these levels. Moreover, social studies and civics curricula are very crowded. There are state mandates for many specialized subjects and many professional organizations and interest groups make claims for their subjects and perspectives. Hence, political science faces a great deal of competition for inclusion in precollege curricula.

- If political science departments are concerned about teacher training, as they should be, then the departments need to establish working relationships with the schools/departments of education on their campuses and to encourage their own political science students to consider teaching careers. (Teachers in the audience described the indifference of their political science faculty and advisors to their career interests.) In addition, departments should organize summer courses and workshops as inservice or continuing education for teachers. Realistically, all elementary teachers and the large majority of secondary school teachers are not political science majors. The profession should work with these teachers and make research on government and politics accessible to them and their students.

\section{Participation by Women in the 1989 APSA Meeting}

\author{
Martin Gruberg \\ University of Wisconsin-Oshkosh
}

How fared women at the 1989 APSA gathering, the 20th anniversary meeting of the Women's Caucus for Political Science? About as well as they scored in 1988, a year of advancement. (Most of the organized sections were incorporated into the Program Committee for the 1989 meeting. This made comparisons with previous years more difficult to derive.)

\begin{tabular}{|c|c|c|c|}
\hline \multicolumn{4}{|c|}{$\begin{array}{c}\text { Grand Totals (Program Committee, } \\
\text { Organized Sections and } \\
\text { APSA Committee Panels) }\end{array}$} \\
\hline Year & Total & Women & $\%$ \\
\hline \multicolumn{4}{|c|}{ Chairpersons } \\
\hline $\begin{array}{l}1984 \\
1985 \\
1986 \\
1987 \\
1988 \\
1989\end{array}$ & $\begin{array}{l}262 \\
333 \\
338 \\
485 \\
347 \\
400\end{array}$ & $\begin{array}{l}54 \\
66 \\
53 \\
79 \\
80 \\
92\end{array}$ & $\begin{array}{l}20.6 \\
19.8 \\
15.7 \\
16.3 \\
23.1 \\
23.0\end{array}$ \\
\hline \multicolumn{4}{|c|}{ Poper Givers } \\
\hline $\begin{array}{l}1984 \\
1985 \\
1986 \\
1987 \\
1988 \\
1989\end{array}$ & $\begin{array}{r}983 \\
1266 \\
1234 \\
1750 \\
1350 \\
1464\end{array}$ & $\begin{array}{l}174 \\
197 \\
239 \\
343 \\
310 \\
336\end{array}$ & $\begin{array}{l}17.7 \\
15.6 \\
19.4 \\
19.6 \\
22.6 \\
23.0\end{array}$ \\
\hline \multicolumn{4}{|c|}{ Discussants } \\
\hline $\begin{array}{l}1984 \\
1985 \\
1986 \\
1987 \\
1988 \\
1989\end{array}$ & $\begin{array}{l}347 \\
383 \\
413 \\
550 \\
435 \\
458\end{array}$ & $\begin{array}{r}64 \\
65 \\
77 \\
101 \\
92 \\
85\end{array}$ & $\begin{array}{l}18.4 \\
17.0 \\
18.6 \\
18.4 \\
21.1 \\
18.6\end{array}$ \\
\hline
\end{tabular}

As usual when women headed sections or panels, there was a greater likelihood of other women being selected for program contributions. Only seven sections were headed by women out of the 36 organized by the Program Committee (19.4\%). Yet these had women as $40 \%$ (36 of 90 ) of the chairpersons, $35.6 \%$ (116 of 326) of the paper givers, and $28.8 \%$ (30 or 104) of the 